\title{
ASSESSMENT OF RADIATION RISK FROM DRINKING WATER AT PUBLIC FOUNTAINS ON THE WIDER TERRITORY OF KRUŠEVAC
}

\author{
BILJANA VUČKOVIĆ ${ }^{*}$ ， NATAŠA TODOROVIĆ ${ }^{2}$ JOVANA NIKOLOV ${ }^{2}$, DRAGAN \\ RADOVANOVIĆ ${ }^{1}$, TIJANA KEVKIĆ ${ }^{1}$
}

${ }^{1}$ Faculty of Natural Science and Mathematics, University of Priština, Kosovska Mitrovica, Serbia

${ }^{2}$ Facucty of Science, Department of Physics, University of Novi Sad, Serbia

\begin{abstract}
Measurements of radon concentrations in drinking waters conducted on wider territory of the town of Kruševac included 16 public fountains, of which 4 are in the city itself and 12 in the surrounding area. Measurements of radon concentrations in water were carried out using radon detector RAD7 (DURRIDGE Co.). The values of radon concentrations in water are in the range of $(5.3 \pm 0.8) \mathrm{Bq}^{-1}$ to $(71.0 \pm 7.2) \mathrm{Bq}^{-1}$ and are below the reference level of $100 \mathrm{~Bq} \mathrm{I}^{-1}$, recommended by the European Commission. Since radon represents one of the most important causes of malignant diseases, annual effective doses of ingestion and inhalation a re determined, whose mean values are in the range of $0.04 \mathrm{mSv}^{-1}$ to $0.52 \mathrm{mSv} \mathrm{y}^{-1}$, and from $14.84 \mu \mathrm{Sv} \mathrm{y}^{-1}$ to $198.8 \mu \mathrm{Sv} \mathrm{y}^{-1}$, respectively. During sampling, water temperatures and their $\mathrm{pH}$ values were measured. These results are the first results of measuring radon in water in this area by this method. The aim of this paper is to evaluate whether there is, or not, a radiological risk to people's health due to the use of water primarily for drinking, but also for other purposes.
\end{abstract}

Keywords: Radon, Water, RAD7, Temperature, pH, Annual effective doses of internal radiation.

\section{INTRODUCTION}

Numerous epidemiological studies have shown that the presence of radon in the environment is considered to be the second most important cause of lung malignancy (immediately after long-term exposure to tobacco smoke) (Manzur et al., 2008; Mitev et al., 2012; Aleissa et al., 2013). Therefore, great attention is paid to investigating the concentration of this radionuclide in water, air (especially indoors) and soil. Radon is a gas without color, odor and taste and therefore cannot be detected by human senses.

As a gas it penetrates the walls and the soil and accumulates in indoor spaces, and the organism is first introduced by inhalation. On the other hand, the solubility of radon in the water and the transport to large distances, allows the accumulation of radon in it, especially if water destroys uranium-rich rocks on its path (Appelton, 2013; Jowzaee, 2013). The resulting radon can be inserted into the water by the effect of the rivers and the flow of groundwater and it can be transported to greater distances. Radon is usually present in significant concentrations in those underground waters that are in contact with granite, gneiss, shale, and also sandstone and limestone. The presence of radon in water is influenced by a number of other factors, such as: water circulation pathways, presence of soluble gases, temperature and pressure, so the concentration of radon at relatively close sites can be different (Todorović et al., 2015). According to the European Commission's recommendation, the upper limit for

\footnotetext{
* Corresponding author: biljana.vuckovic@pr.ac.rs
} PHYSICS radon concentration in groundwater that can be used for drinking is $100 \mathrm{~Bq}^{-1}$ (WHO, 2004; European Commission, 2013). When radon-rich groundwater reaches the surface (springs, wells, public fountains), the concentration of radon in the water will rapidly decline during its movement and purification. Generally, groundwater is characterized by a higher concentration of radon from surface waters. However, if such water is used for drinking, or for some other purpose directly from the place of origin, as it is usual in the rural environment, there will still be a high concentration of radon, and the time elapsed from collection to consumption will not be enough to potential health risks associated with radon and its short-lived offspring would be prevented (Galan et al., 2004). It is therefore important to control the concentration of radon in water at the sources and public fountains in order to determine whether it is safe from the radiological point of view.

In human body, radon can be introduced by ingestion and inhalation, with an effective dose in the first place depending on its concentration in water, metabolism and kinetics in the body. Since radon is an aqua-phobic, and easily leaves the water, its presence in the water does not pose a direct danger to health (Todorović et al., 2012), but the radon released from such water indoor air will enhance indoor radon. Therefore, great attention is paid to measuring of radon concentration indoor radon atmosphere (Žunić et al., 2006; Nikolov et al., 2012). It was estimated that the inhalation of radon and its offspring, released from drinking water, caused as much as $89 \%$ of lung cancer, while the remaining $11 \%$ of the carcinoma in the first order of the digestive tract was due to ingestion of water with increased radon concentrations (USEPA, 1999). 
An important parameter of water is relative acidity or alkalinity, which is determined by measurement of $\mathrm{pH}$ value. Low $\mathrm{pH}$ value is the most important parameter linked to the high radium concentration, because it is readily soluble in low pH water (Sharma \& Sharma, 2013; Kasić et al., 2016). Another important parameter that affects the presence of radon in water is temperature. It is noticed that content of radon in water decreases with an increase in temperature (Cothern, 1987).

This study presents the results of measurements of radon concentrations in water sampled on 16 public fountains on wider territory of the city of Kruševac. On the basis of the obtained values, the effective doses of inhalation and ingestion of radon were determined annually and summed up in the total dose of radiation exposed to the population in the area.

\section{STUDY AREA}

Kruševac $\left(43^{\circ} 35^{\prime} \mathrm{N}, 21^{\circ} 19^{\prime} \mathrm{E}\right)$ is a city located in the central part of Serbia. According to the official census, the city has 64500 inhabitants, while on the wider territory of the city there are 131386 inhabitants. Figure 1 shows the map of 16 investigated locations.

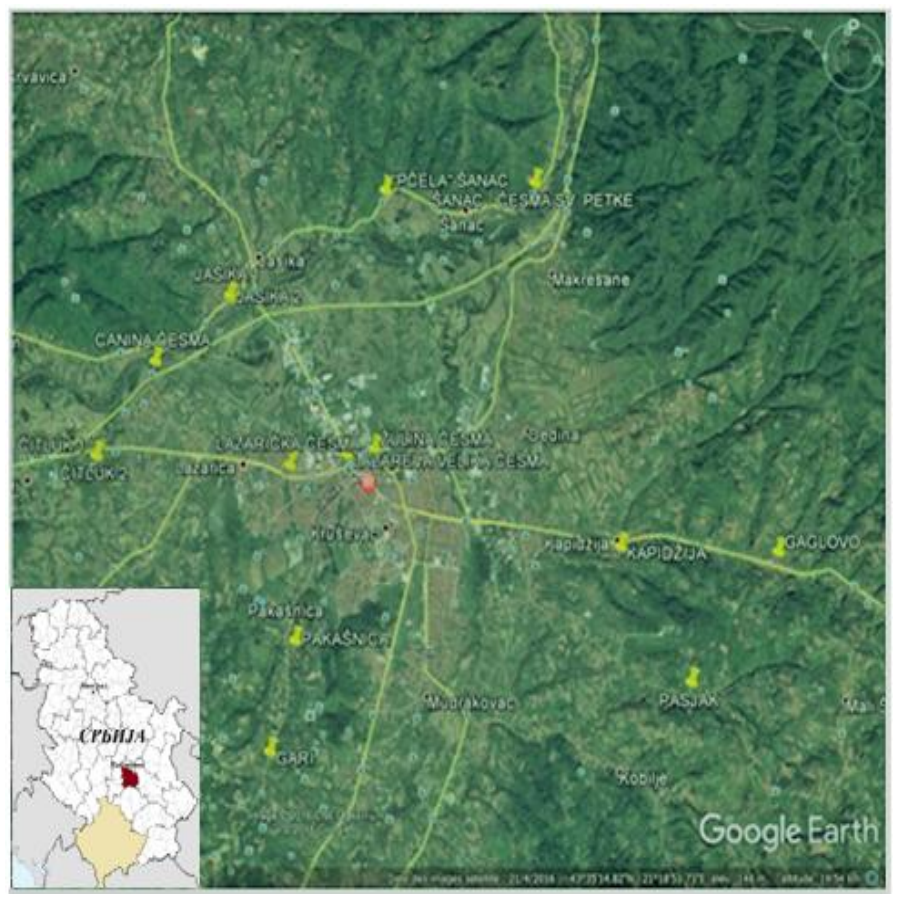

Figure 1.Map of investigated area.

When looking at the geological structure of the investigated area, it is noted that the oldest crevices are crystalline shards of high degree of metamorphism, mostly of sedimentary origin. Among them, two complexes are distinguished: (1) ectic, within the Bloc of Big Jastrebac and smaller parties in the Kruševac neogenogen basin, and (2) magmatical, in the Mojsina Mountains with the presence of striated biotic and muscular gneisses.
In the area of Kruševac depression, that is, the largest part of the area investigated, there are the trenches of Drenova, Rasina and Dedina (Geological atlas of Serbia, 1999). Of the 16 explored public fountains 6 , there are neogeneous clay, sand and gravel - "Pčela" Šanac, Kapidžija, Gaglovo, Jasika 1 and Jasika 2. On the pleistocene river terraces of the West Morava and Rasina there are Canina fountain, Čitluk 1 and Čitluk 2, fountain near FAM gate, the Lazareva big fountain and the Zulina fountain. Gari and Pakašnica are found on neogeneous clay, sand and gravel. Lazaric fountain is located on holocene alluvium, and the fountain of Sv. Petke in Šanac is located on crystalline shales of high degree of metamorphism.

\section{EXPERIMENTAL}

\section{Materials and methods}

In this study, radon concentration in water was measured by alpha spectrometer RAD7 (Durrige Co.) in Laboratory for Nuclear Physic at the Faculty of Science, University of Novi Sad. The base of this device is a hemisphere chamber of 0.71 capacity, which inner side is coated with a material that is a good conductor. In the center of the chamber there is a silicon $\alpha$ detector. At the inlet to the chamber there is a filter that prevents the entrance of radon progenies in the chamber and thus allows the measurement of only radon concentrations in it. The high voltage electric field (2000-2500 V) inside the detector chamber accelerates and directs to the surface of detector only positive ion of Po-218 originated from radon decay. The deposited Po-218 emits $\alpha$-particles that, with a probability of $50 \%$, enter the active volume $\mathrm{n}$ of detector and produce an electric signal which intensity corresponds to the energy of incident alpha particle.

In order to measure radon concentration in water $\mathrm{RAD}_{2} \mathrm{O}$ accessory to RAD7 detector was used with grab sampling method and two available protocols Wat-40 or Wat-250. It enables the aeration of sampled water are removing the available radon from water into the measurement chamber. The efficiency of extraction of radon from water into the air circulating to the measuring chamber depends slightly on the ambient temperature, but it is always greater than $90 \%$. After 5 minutes of aeration in the measurement system equilibrium is reached, and there is no more radon that could be extracted from the sample. If the radon concentration is lower than $100 \mathrm{~Bq} \mathrm{l}^{-1}$, the usage of $250 \mathrm{ml}$ bottles is recommended, with the extraction efficiency $94 \%$. Otherwise, the water should be sampled in $40 \mathrm{ml}$ bottles, where the extraction efficiency is $99 \%\left(\mathrm{RAD} 7 \mathrm{RAD} \mathrm{H}_{2} \mathrm{O}\right.$ ).

\section{RESULTS AND DISCUSSION}

Within this study, waters from public fountains were sampled in 1.5-liter plastic bottles. During the sampling battles must be filled up to the very top and closed under a jet of water 
to prevent accumulation of radon under the lid. The results measurements are summarized and presented in Table 1.

Table 1. Results of measurements at 16 investigating locations.

\begin{tabular}{|l|l|l|l|l|l|l|}
\hline $\begin{array}{l}\text { No. } \\
\text { Location }\end{array}$ & $\begin{array}{l}\mathrm{T} \\
\left({ }^{\circ} \mathrm{C}\right)\end{array}$ & $\mathrm{pH}$ & $\begin{array}{l}\mathrm{C}_{\mathrm{o}} \\
\left(\mathrm{Bql}^{-1}\right)\end{array}$ & $\begin{array}{l}\mathrm{C}_{\text {corr }} \\
\left(\mathrm{Bql}^{-1}\right)\end{array}$ & $\begin{array}{l}\mathrm{E}_{\text {ingest }} \\
(\mathrm{mSv} \\
\left.\mathrm{y}^{-1}\right)\end{array}$ & $\begin{array}{l}\mathrm{E}_{\text {inhal }} \\
(\mu \mathrm{Sv} \\
\left.\mathrm{y}^{-1}\right)\end{array}$ \\
\hline $\begin{array}{l}1 . \\
\text { Gari }\end{array}$ & 14 & 7.14 & $2.4 \pm 0.5$ & $6.0 \pm 1.2$ & 0.04 & 16.80 \\
\hline $\begin{array}{l}2 . \\
\text { Pakašnica }\end{array}$ & 14 & 7.34 & $7.7 \pm 1.0$ & $19.2 \pm 2.5$ & 0.14 & 53.76 \\
\hline $\begin{array}{l}3 . \\
\text { Lazaric }\end{array}$ & 12 & 7.02 & $10.1 \pm 1.7$ & $30.1 \pm 5.1$ & 0.21 & 84.28 \\
\hline $\begin{array}{l}4 . \\
\text { FAM gate }\end{array}$ & 16 & 7.75 & $2.3 \pm 0.5$ & $6.7 \pm 1.4$ & 0.05 & 18.76 \\
\hline $\begin{array}{l}\text { 5. } \\
\text { Lazareva }\end{array}$ & 15 & 6.90 & $1.8 \pm 0.3$ & $5.3 \pm 0.8$ & 0.04 & 14.84 \\
\hline $\begin{array}{l}\text { 6. } \\
\text { Zulina }\end{array}$ & 16 & 6.94 & $3.4 \pm 0.5$ & $10.0 \pm 1.5$ & 0.07 & 28.00 \\
\hline $\begin{array}{l}7 . \\
\text { "Pčela" } \\
\text { Sanac }\end{array}$ & 13 & 6.95 & $4.7 \pm 1.0$ & $14.1 \pm 3.0$ & 0.10 & 39.48 \\
\hline $\begin{array}{l}8 . \\
\text { Pasjak }\end{array}$ & 15 & 6.93 & $3.7 \pm 0.7$ & $10.7 \pm 2.0$ & 0.08 & 29.96 \\
\hline $\begin{array}{l}9 . \\
\text { Kapidžija }\end{array}$ & 13 & 6.99 & $2.2 \pm 1.1$ & $6.5 \pm 3.2$ & 0.05 & 18.20 \\
\hline $\begin{array}{l}10 . \\
\text { Gaglovo }\end{array}$ & 14 & 7.19 & $3.8 \pm 0.3$ & $11.4 \pm 0.9$ & 0.08 & 31.92 \\
\hline $\begin{array}{l}11 . \\
\text { Jasika 1 }\end{array}$ & 12 & 6.91 & $10.5 \pm 2.1$ & $14.9 \pm 2.9$ & 0.11 & 41.72 \\
\hline $\begin{array}{l}12 . \\
\text { Jasika 2 }\end{array}$ & 14 & 7.06 & $9.2 \pm 0.9$ & $13.1 \pm 1.3$ & 0.09 & 36.68 \\
\hline $\begin{array}{l}13 . \\
\text { Sv.Petka } \\
\text { Sanac }\end{array}$ & 11 & 6.87 & $45 \pm 4$ & $64.8 \pm 5.8$ & 0.47 & 181.44 \\
\hline $\begin{array}{l}14 . \\
\text { Citluk 1 }\end{array}$ & 13 & 5.82 & $49 \pm 5$ & $71.0 \pm 7.2$ & 0.52 & 198.80 \\
\hline $\begin{array}{l}15 . \\
\text { Canina }\end{array}$ & 12 & 6.65 & $6.4 \pm 2.0$ & $11.2 \pm 3.5$ & 0.08 & 31.36 \\
\hline $\begin{array}{l}16 . \\
\text { Čitluk 2 }\end{array}$ & 14 & 5.9 & $10.8 \pm 1.3$ & $19.1 \pm 2.3$ & 0.14 & 53.48 \\
\hline
\end{tabular}

Since the concentration of radon could not be measured at the sampling point, it was very important that the time elapsed from sampling to measurement was reduced to a minimum, due to the decay of radon (half-life is 3.82 days). In addition to the measured radon concentration $\mathrm{C}_{\mathrm{o}}$, its decay correlated value $\mathrm{C}_{\text {corr }}$ is determined as follows (Todorović et al., 2012):

$$
C_{\text {corr }}=C_{o} \cdot e^{(-(\ln 2 \cdot t) / T 1 / 2)}
$$

where time $\mathrm{t}$ defined the time elapsed from sampling to radon concentration measurement, which was in interval from 2 to 6 days in this study.

The results indicate that the concentration of radon in water ranges from 5.3 $\mathrm{Bq}^{-1}$ - for Lazaric fountain to 71.0 $\mathrm{Bq}^{-1}-$ for Čitluk1, with a mean value of $19.69 \mathrm{~Bq} \mathrm{l}^{-1}$ and a standard deviation of $19.9 \mathrm{~Bq} \mathrm{l}^{-1}$. Slightly elevated radon concentrations were detected in waters from the fountain of Sv. Petka in Šanac$\left(64.8 \mathrm{~Bq}^{-1}\right)$ and Čitluk1 (71.0 $\left.\mathrm{Bq}^{-1}\right)$, which is expected for the geological structure of the location terrain. However, result for Čitluk 2 indicates that although it is located in the same geological area, the difference in radon concentration is evident, which is probably due to various underground flows of these waters.

The radon concentrations present in this study are somewhat higher than, for instance, those measured in other part of Serbia: $(4.6 \pm 8.5) \mathrm{Bq} \mathrm{l}^{-1}$ to $(18.6 \pm 1.3) \mathrm{Bq}^{-1}$ (Todorović et al., 2012) and $\left(7 \pm 1 \mathrm{~Bq} \mathrm{l}^{-1}\right)$ to $\left(21 \pm 2 \mathrm{~Bq} \mathrm{l}^{-1}\right)$, except $149 \pm 12 \mathrm{~Bq} \mathrm{l}^{-1}$ in Niska Banja (Vučković et al., 2014) and in the region: (4.0 to 17.4) $\mathrm{Bq} \mathrm{l}^{-1}$ (Radolić et al., 2008) and (214 to 3702) $\mathrm{mBq} \mathrm{l}^{-1}$ (Kasić et al., 2016), but still below the proposed reference level of the EU Commission Recommendation.

A low pH value of 5.82 measured in Čitluk1 water sample also indicates an increased presence of radon. But it is not possible to speak in general terms about the correlation between radon water concentration and $\mathrm{pH}$ value, which can be seen in Figure 2, which is confirmed by the small value Pearson's coeficient $r=0.26$.

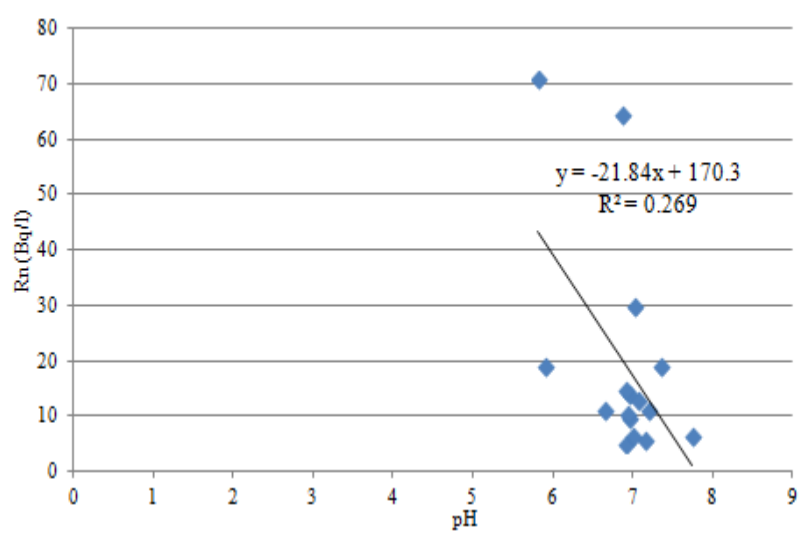

Figure 2. Correlation between radon concentrations and $\mathrm{pH}$ values of the water samples.

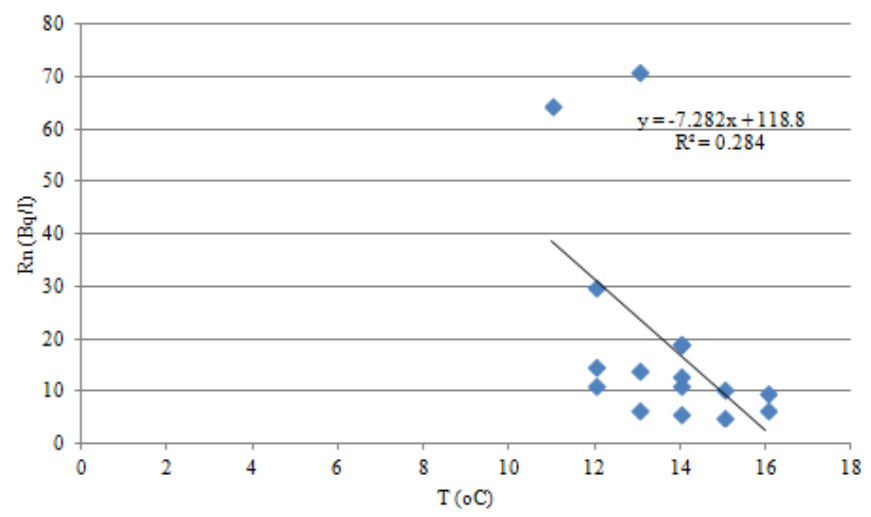

Figure 3. Correlation between radon concentrations and the temperatures of the water samples.

The temperature of the sampled waters is in the range of $11^{\circ} \mathrm{C}$ - for the fountain of Sv. Petka up to $16^{\circ} \mathrm{C}$ - for Zulina fountain and fountain near FAM gate and has no effect on the 
concentration of radon in water, as indicated by the value of the factor $\mathrm{r}=0.28$, Figure 3 .

\section{Annual effective doses of internal radiation}

For the control of the population exposure to natural sources of radiation, the concentration of radon in drinking water is a relevant parameter dose assessment (Kumar et al., 2016). The total effective dose of internal irradiation with radon dissolved in water consists of two components: the first defines the effective dose of ingestion, while the other defines the effective dose of radon inhalation.

Radon-rich water goes directly into the stomach, where radon can diffuse the body through the walls of the stomach to radiosensitive cells in the body. Part of the injected radionuclide can remain in the same sites for a long time, and some may be linked to macrophages and transferred further to the lymphatic cells. These cells can receive radiation doses of $\alpha$-particles emitted during the decay of radon and its short-lived progeny in the stomach wall (UNSCEAR, 2008). The range of $\alpha$-particles in the tissues is (40-70) $\mu \mathrm{m}$, depending on their energy. The effective dose received from the ingestion of radon and its progeny and related to gastric tissue, expressed in $\mathrm{mSv}^{-1}$, is determined as follows (WHO, 2003):

$$
E_{\text {ing }}=K \times C_{R n} \times K M \times t
$$

where: $\mathrm{K}$ is a conversion factor of $10^{-8} \mathrm{~Sv} \mathrm{~Bq}^{-1}$ for adults, and $2 \times$ $10^{-8} \mathrm{~Sv} \mathrm{~Bq}^{-1}$ for children (WHO, 2003); $\mathrm{C}_{\mathrm{Rn}}$ is the concentration of radon in water; $\mathrm{KM}$ is a consumption factor (optimal $2 \mathrm{l} / \mathrm{d}$ ) and $\mathrm{t}$ is time of 365 days (USEPA, 1999). Since the concentration of radon in water decreases over time, the effective dose of ingestion refers to the initial concentration of radon in water (European Commission, 1998). The annual effective radiation dose by ingestion of radon inlet is in the interval from $0.04 \mathrm{mSv} \mathrm{y}^{-1}$ (Gari and Lazareva fountain) to $0.52 \mathrm{mSv} \mathrm{y}^{-1}$ (Čitluk 1), with mean value of $0.14 \mathrm{mSv}^{-1}$ and standard deviation of $0.14 \mathrm{mSv} \mathrm{y}^{-1}$.

It should be emphasized that the radiation dose in the lungs is mainly derived from radon short-lived daughters in bronchioles and it is less than dose form radon itself. Radon is largely thrown out of the lungs by the exhausted air. Inhalation of radon progeny can lead to inhomogeneous deposition on the human respiratory tract and bronchial epithelium, which increases the risk of lung cancer. The dose received by inhalation of radon depends on the diameter of the inhaled surrounding particles of aerosols which are generally descended by the fetus and can vary by a factor of $\sim 2$ in normal home conditions. The effective dose of inhalation received by the lung tissue is obtained by multiplying the concentration of radon in water by a conversion factor of $2.8 \mu \mathrm{Sv} \mathrm{Bq}^{-1} \mathrm{~m}^{3}$ (WHO, 2003). Based on the present concentration of radon, the annual effective dose of inhalation is in the range of $14.84 \mu \mathrm{Sv} \mathrm{y}^{1}$ for Lazareva fountain

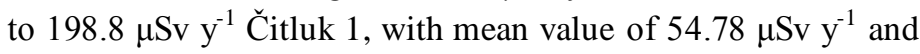
standard deviation of $55.8 \mu \mathrm{Sv} \mathrm{y}^{-1}$.

\section{CONCLUSION}

The highest concentrations of radon were measured in the water samples from the Čitluk 1 and the fountain of Sv. Petka and yeald $71.0 \mathrm{~Bq} \mathrm{l}^{-1}$ and $64.8 \mathrm{~Bq} \mathrm{l}^{-1}$, respectively. The lowest concentration was measured in the water sample from the Lazarian fountain and yeald $5.3 \mathrm{~Bq} \mathrm{l}^{-1}$. The results of this study indicate that the concentrations of radon in water samples taken from public fountains at 16 different locations with a mean value of $19.72 \mathrm{~Bq} \mathrm{l}^{-1}$ indicate that the radon concentrations in public drinking water samples are mostly low enough and below the proposed reference level of the EU Commission Recommendation. On that basis, it can be concluded that the water of these public fountains from the radiation aspect can be safely used for drinking, but also for other purposes. Unfortunately, up till now, there is no specific national regulation for the radon content in drinking water in Serbia.

On the variation of radon concentration in water of great influence, the geological structure of the terrain on which the fountain is located, as well as the path of groundwater movement, indicates a significant concentration of radon in a sample of water from Čitluk 1 from $71.0 \mathrm{~Bq} \mathrm{l}^{-1}$ to which the groundwater comes passing through shards and sands.

The temperature of the sampled waters is in the range of $11^{\circ} \mathrm{C}$ for the fountain of Sv. Petka up to $16^{\circ} \mathrm{C}$ for Zulina fountain and fountain near FAM gate with no effect on the concentration of radon in water. The measured $\mathrm{pH}$ value is in the range of 5.82 (Čitluk 1) to 7.75 (fountain near FAM gate) and is not accompanied by a fully enhanced presence of radon in water.

The mean values of the effective doses of inhalation and ingestion of radon at the annual level are $0.14 \mathrm{mSv} \mathrm{y}^{-1}$ and 55.21 $\mu \mathrm{Sv} \mathrm{y}^{-1}$, respectively and indicate that the water of these public fountains from the radiation aspect can be safely used for drinking, but also for other purposes optionally. It should indicate the significant contribution of the manuscript with its applications.

\section{ACKNOWLEGMENTS}

This study is a part of the research done within the project no. IJ01-17 supported by the Faculty of Natural Sciences and Mathematics, University of Priština, Kosovska Mitrovica.

\section{REFERENCES}

Aleissa, K. A., Alghamdi, A. S., Almasoud, F. I., \& Islam, M. S. 2013. Measurement of radon levels in groundwater supplies of Riyadh with liquid scintillation counter and the associated radiation dose. Radiation Protection Dosimetry, 154(1), pp. 95-103. doi:10.1093/rpd/ncs140

Appleton, J. D. 2013. Radon in air and water. In O. Selinus Ed., Essentials of Medical Geology: Impacts of the Natural Environment on Public Health. Elsevier Amsterdam, pp. $227-$ 262. 
Cothern, C., \& Smith, J. E. 1987. Environmental Radon. New York: Plenum Press.

-Durridge Co. RAD7 RAD H2O: Radon in Water Accessory.

-European Commission. 2013. Council Directive 2013/51/ EURATOM of 22 October 2013: Laying down requirements for the protection of the health of the general public with regard to radioactive substances in water intended for human consumption. Off J. Eur. Commun, L296:12-21.

-European Commission. 1998. European drinking water directive 98/83/EC of 3rd November 1998 on the quality of water intended for human consumption. Official J L, pp. 330.

Galán, L. M., Martín, S. A., \& Gómez, E. V. 2004. Application of ultra-low level liquid scintillation to the determination of $222 \mathrm{Rn}$ in groundwater. Journal of Radioanalytical and Nuclear Chemistry, 261(3), pp. 631-636. doi:10.1023/b:jrnc.0000037106.78880.d0

Jowzaee, S. 2013. Determination of selected natural radionuclide concentrations in southwestern Caspian groundwater using liquid scintillation counting. Radiation Protection Dosimetry, 157(2), pp. 234-241. doi:10.1093/rpd/nct132

Kasić, A., Kasumović, A., Adrović, F., \& Hodžić, M. 2016. Radon measurements in well and spring water of the Tuzla area, Bosnia and Herzegovina. Archives of Industrial Hygiene and Toxicology, 67(4), pp. 332-339. doi:10.1515/aiht-2016-67-2788

Kumar, A., Kaur, M., Sharma, S., \& Mehra, R. 2016. A study of radon concentration in drinking water samples of Amritsar city of Punjab (India). Radiation Protection and Environment, 39(1), p. 13. doi:10.4103/0972-0464.185155

Manzoor, F., Alaamer, A. S., \& Tahir, S. N. A. 2008. Exposures to $222 \mathrm{Rn}$ from consumption of underground municipal water supplies in Pakistan. Radiation Protection Dosimetry, 130(3), pp. 392-396. doi:10.1093/rpd/ncn156

-Ministry of Mining and Energy of Serbia. 1999. Geologicam maps: 1:2.000 000. In Geological Atlas of Serbia. Beograd: Geomagnetic Institute; Beograd: Barex. second edition, No. 2, on Serbian.

Mitev, K., Dimitrova, I., Zhivkova, V., Georgiev, S., Gerganov, G., Pressyanov, D., \& Boshkova, T. 2012. Measurement of $\mathrm{Rn}-222$ in water by absorption in polycarbonates and liquid scintillation counting. Nucl Instrum Meth, 677, pp. 31-40.

Nikolov, J., Todorović, N., Petrović Pantić, T., Forkapić, S., Mrđa, D., Bikit, I., Krmar, M., \& Vesković, M. 2012. Exposure to radon in the radon spa Niška Banja, Serbia. Radiation Measurements, 47(6), pp. 443-450. doi:10.1016/j.radmeas.2012.04.006
Radolić, V., Šarić, I., \& Miklavčić, I. 2008. Radon u vodi gradskih vodovoda u naseljima Požeško-slavonske županije [Radon in public waterworks of the cities of Požega-Slavonia County]. In D. Barišić, Ž. Grahek, B. I. Krajcar, \& S. Miljanić Eds., Proceedings of the Seventh Symposium of the Croatian Radiation Protection Association, Opatija, Croatia.Zagreb: Croatian Radiation Protection Association. pp. 294-299. May; 29-31, on Croatian.

Sharma, N., \& Sharma, R. 2013. Survey of radon concentration in drinking water samples of Hoshiarpur and Ropar districts of Punjab, India. Adv Appl Sci Res, 4, pp. 226-31.

Todorović, N., Nikolov, J., Petrović, P. T., Kovačević, J., Stojković, I., \& Krmar, M. 2015. Radon in Water: Hydrogeology and Health Implication. New York: Nova Science Publishers.

Todorovic, N., Nikolov, J., Forkapic, S., Bikit, I., Mrdja, D., Krmar, M., \& Veskovic, M. 2012. Public exposure to radon in drinking water in Serbia. Applied Radiation and Isotopes, 70(3), pp. 543-549.

doi:10.1016/j.apradiso.2011.11.045

-United Nations Scientific Committee on the effects of Atomic Radiation (UNSCEAR). 2008. Sources and effects of Ionizing Radiation. In Report to the General Assembly with Scientific Annexes. New York: United Nations.

-US Environmental Protection Agency (USEPA). 1999. Radon in drinking water health risk reduction and cost analysis: EPA Federal Register. Washington, DC: Office of Radiation Programs. 64.

Vuckovic, B., Gulan, Lj., Milic. L. G., , Adrovic, F., \& Radovanovic, D. 2014. Ovreview of radon concentrations in air and in water in Serbian spas. In Proceedings of Second East Europiean Radon Symposium SEERAS. Niš, Serbia. pp 39-42. May; 27-30.

-World Health Organisation (WHO). 2004. Guidelines for drinking water quality. Geneva. 3rd ed.

-World Health Organization (WHO). 2003. Guidelines for drinking water quality: Health Criteria and Other Information. Geneva.

Žunić, Z. S., Kobal, I., Vaupotič, J., Kozak, K., Mazur, J., Birovljev, A., Janik, M., Čeliković, I., Ujić, P., Demajo, A., Krstić, G., Jakupi, B., Quarto, M., \& Bochicchio, F. 2006. High natural radiation exposure in radon spa areas: A detailed field investigation in Niška Banja (Balkan region). Journal of Environmental Radioactivity, 89(3), pp. 249-260. doi:10.1016/j.jenvrad.2006.05.01 